Paulina Pludra-Żuk

Warszawa

\title{
Tradycja rękopiśmienna Kroniki dwudziestu czterech generałów Zakonu Braci Mniejszych na ziemiach polskich - nowe rękopisy ${ }^{1}$
}

\section{Kronika dwudziestu czterech generatów}

na tle historiografii franciszkańskiej

W pierwszej połowie trzynastego wieku pojawia się w Europie i szybko rozwija nowe zjawisko - zakony mendykanckie. Powstałe w ścisłym związku z rozwojem demograficznym miast same zaczynają od razu wpływać na ich społeczność, dziedzicząc jednocześnie po poprzednich wiekach kontemplacyjną część życia zakonnego². Szybki rozwój liczebny, zinstytucjonalizowanie zakonu i przyjęta rola już pierwszemu pokoleniu franciszkanów uświadamiają konieczność przywiązania szczególnej wagi do zakonnej edukacji, a zarazem są bodźcem do rozwoju literatury, skupiającej się wokół głównych zadań zakonu. Zarówno vita contemplativa, z przejętym po epoce monastycznej centralnym miejscem, jakie zajmowała w nim egzegeza biblijna, jak i vita activa, która w zakonach mendykanckich przyjęła nową formę, obejmując swoim oddziaływaniem różnorodny krąg odbiorców, oparły się na szeroko pojętej historiografii. Popularność, jaką we franciszkańskim pojmowaniu historii zyskała wywodząca się od Ruperta z Deutz i rozwinięta później m.in. przez Joachima z Fiore szkoła egzegetyczna, która w wydarzeniach współczesnych szukała analogii do Pisma Świętego, pozwoliła na postrzeganie własnych dziejów jako odpowiedzi na Ewangelię. Historia była też obe-

${ }^{1}$ Chciałabym podziękować o. Zenonowi Stysiowi OFM i s. Genowefie Godlewskiej (Biblioteka Franciszkańskiego Centrum dla Europy Wschodniej i Azji Północnej w Warszawie) za pomoc w zgromadzeniu materiałów oraz panu Sławomirowi Szyllerowi za cenne uwagi.

${ }^{2}$ John V. Fleming, An Introduction to the Franciscan Literature of the Middle Ages, Chicago 1977, s. 8-9. 
cna w społecznym aspekcie działalności zakonu. Te dwie dziedziny życia franciszkanów leżą u podstaw rozwoju kilku związanych z historiografią gatunków literackich ${ }^{3}$.

Najpierw, zarówno ze względu na chronologię jak i znaczenie, należy wymienić żywoty św. Franciszka. Wśród nich pierwszą grupę stanowią utwory spisane przez Tomasza z Celano 4 (najstarszy powstał prawdopodobnie w roku 1229), drugą zaś teksty autorstwa św. Bonawentury opracowane po kapitule generalnej w roku 1260. Jako osobne teksty funkcjonują też żywoty Antoniego Padewskiego i Idziego, pozostałe, razem z fragmentami dotyczącymi świętych klarysek i członków trzeciego zakonu, wplatane są w kroniki, zbiory legend, katalogi, zestawienia egzemplów, zbiory kazań, teksty liturgiczne i różne utwory o charakterze miscellaneum. Około roku $1260^{5}$ za sprawą wykształcenia się franciszkańskich ośrodków nauki, dających dostęp do literatury, a jednocześnie w związku z narastaniem kontrowersji wokół kwestii ubóstwa, następuje przeniesienie punktu ciężkości z zainteresowania samym Franciszkiem na całą fraternitas ${ }^{6}$. W następstwie tych zmian zaczynają powstawać najpierw kroniki lokalne o różnym zasięgu, dotyczące historii franciszkanów na terenie poszczególnych państw czy prowincji, a następnie kroniki obejmujące historię całego zakonu. Dużą grupę tekstów stanowią również pisma historiograficzne, które, choć stworzone w środowisku franciszkańskim, podejmują temat historii szerzej i często nie akcentują wydarzeń związanych z zakonem. Spośród nich najogólniej o historii traktują kroniki uniwersalne, węższy obszar obejmują te, które nazwać można narodowymi, jeszcze węższy - dzieje miast. Związek franciszkanów z ośrodkami miejskimi był na tyle istotny, że można

${ }^{3}$ Co się tyczy szczegółowej charakterystyki historiografii franciszkańskiej i bibliografii tematu, zob. Bert Roest, Reading the Book of History. Intellectual Contexts and Educational Functions of Franciscan Historiography 1226-ca. 1350, Groningen 1996. Na tej publikacji, jeśli nie zostało zaznaczone inaczej, opieram poniższy wstęp dotyczący historiografii franciszkańskiej.

${ }^{4} \mathrm{O}$ żywotach św. Franciszka autorstwa Tomasza z Celano traktuje wstęp do: Tomasza z Celano biografie św. Franciszka, „Źródła Franciszkańskie”, t. 3, pod red. Rafała Witkowskiego, Poznań-Warszawa 2007, s. 17-66.

${ }^{5}$ Zob. B. Roest, dz. cyt., s. 33.

${ }^{6}$ Jak twierdzi Michael F. Cusato trzy wydarzenia wpłynęły na rozszerzenie zainteresowania na historię całego zakonu. Były to: (1.) wydanie przez papeża Grzegorza IX bulli Quo elongati, w której Testament św. Franciszka uznany zostaje za niewiążący, (2.) odwołanie z funkcji generała Eliasza z Kortony i związana z tym kontrowersja w spojrzeniu na rolę w historii Fryderyka II, oraz (3.) wydanie przez Innocentego IV bulli Ordinem vestrum, dającej zakonnikom swobodę w dysponowaniu pieniędzmi. Zob. M. F. Cusato, Talking About Ourselves: The Shift in Franciscan Writing from Hagiography to History (1235-1247), „Franciscan Studies”, 58:2000, s. 37-75. 
wręcz mówić o specyficznych cechach kronik miejskich spisanych w tym środowisku ${ }^{7}$. A jako że działalność duszpasterska mendykantów koncentrowała się przede wszystkim $\mathrm{w}$ miastach i na terenach podmiejskich, również z tym obszarem łączyły się zbiory egzemplów. Znanych jest kilkanaście tego rodzaju zestawień pochodzących z kręgu franciszkańskiego ${ }^{8}$. Cechą, która wyróżnia je na tle kompilacji stworzonych w innych środowiskach, jest ciągły rozwój korpusu „przykładów” nawet jeszcze w XV w., kiedy to kompilatorzy na ogół ograniczali się już tylko do zasobu egzemplów znanych wcześniej. Do pełnej panoramy literatury, która według średniowiecznych pojęć zawiera elementy historiograficzne $^{9}$, dodać należy ponadto teksty związane z misjami ewangelizacyjnymi i dyplomatycznymi, zarówno z ramienia władz duchowych, jak świeckich. Do tego typu literatury zaliczają się przede wszystkim przewodniki po Ziemi Świętej, w której franciszkanie szybko zaczęli pełnić szczególnie istotną rolę, a od 1342 r. stali się w niej oficjalnymi przedstawicielami Kościoła katolickiego. Do podobnej kategorii należą traktaty mówiące o konieczności odzyskania Ziemi Świętej przez chrześcijan (traktaty de recuperatione). Innym kierunkiem zainteresowań stał się Daleki Wschód. Wśród tekstów związanych z wyprawą Jana di Piano Carpini do Mongolii w latach 1245-1247 znalazła się również Relatio autorstwa pochodzącego z terenów polskich Benedykta ${ }^{10}$. Zaznaczyć też należy, że istotną rolę odegrały teksty wywodzące się ze spirytualnego odłamu zakonu.

W tej pobieżnej panoramie szczególne miejsce zająć powinny utwory historiograficzne sensu stricto dotyczące historii całego zakonu. Pierwszym takim tekstem była prawdopodobnie spisana w 1290 r. przez Filipa z Perugii Historia Ordinis Minorum, której do dziś nie zidentyfikowano. Następnie powstawać zaczęły kroniki zorganizowane wokół list generałów zakonu. Pierwszym takim spisem był anonimowy Catalogus Generalium Ministrorum z roku 1304. Zostały w nim zawarte dzieje zakonu za czasów pierwszych czternastu generałów. Również z tego mniej wię-

${ }^{7}$ François Fossier, La ville dans l'historiographie franciscaine de la fin du XIII et $d u$ début du XIV $V^{e}$ siècle, „Mélanges de l'École française de Rome. Moyen-Âge, Temps modernes", 89/2 (1977), s. 641-655.

${ }^{8}$ Jean-Claude Schmitt, Franciszkańskie zbiory exemplów. Udoskonalenie technik intelektualnych (XIII-XV w.), „Zakony franciszkańskie w Polsce”, t. I., cz. 2 i 3, Kraków 1989, s. 93-104.

${ }^{9}$ B. Roest, dz. cyt., s. 101.

${ }^{10}$ Zob. Spotkanie dwóch światów. Stolica Apostolska a świat mongolski w połowie XIII wieku: relacje powstałe w zwiazku z misją Jana di Piano Carpiniego do Mongotów, pod red. Jerzego Strzelczyka, Poznań 1993. 
cej czasu pochodzi zwięzłe, spisane $\mathrm{w}$ formie listu Peregryna $\mathrm{z}$ Bolonii do Gonsalwa z Valboa, zestawienie rządów osiemnastu generałów z zaznaczeniem najważniejszych współczesnych im wydarzeń - Chronicon Abbreviatum de Successione Generalium Ministrorum. Tego samego okresu dotyczy anonimowa Cronica XIV vel XV generalium. Podobny charakter miały również dziś niezachowane prace Filipa Brusserio. Szczytowym osiągnięciem tego gatunku jest natomiast Cronica XXIV generalium $^{11}$, która, uważana za dzieło wtórne, do niedawna nie cieszyła się zainteresowaniem uczonych.

W połowie siedemnastego wieku kwestię autorstwa Kroniki dwudziestu czterech generatów porusza L. Wadding ${ }^{12}$, przypisując je (bez podania źródeł tej informacji) Arnaldowi z Sarrant ${ }^{13}$, ministrowi prowincji Akwitanii w latach 1361-1381 i autorowi pochodzącego z roku 1365 zestawienia życia świętego Franciszka i Chrystusa - De cognatione sancti Francisci $^{14}$. Tezę tę zdaje się potwierdzać wewnętrzna krytyka tekstu. Autor koncentruje się na informacjach dotyczących Francji (zauważalna jest też przewaga wzmianek o francuskich świętych), szczególnie zaś często odnosi się do Akwitanii i sięga do przechowywanych na jej terenie źródeł ${ }^{15}$. Ponadto do postaci Arnalda pasuje szerokie wykorzystanie materiałów, do których mógł mieć dostęp prowincjał, informacje zebrane z terenów Półwyspu Iberyjskiego, gdzie prowadził działania reformatorskie, jak i reformatorska wymowa tekstu.

11 Wydanie: Chronica XXIV Generalium Ordinis Minorum, „Analecta Franciscana”, t. III, Quaracchi 1897 (dalej cyt.: Chron. XXIV Gen.).

${ }^{12}$ Wadding stwierdza: „Hic cuncta, quae potuit de sancti Francisci vita et moribus collegit: et a quibusdam iudicatur auctor Chronicorum XXIV generalium" (Annales minorum seu trium ordinum a S. Francisco institutorum, t. 8, Romae 1733, s. 333).

${ }^{13}$ Postać Arnalda z Sarrant (nazwa miejscowości funkcjonowała w wielu wersjach, m.in. Serrano, Serano, czy Sarnano) pojawia się w czterech listach papieża Grzegorza IX: pierwszym, z roku 1371 potwierdzającym wybór opatki klasztoru klarysek w Pamiers (Bullarium Franciscanum VI, n. 1113, s. 458); drugim, z roku 1373, w którym poleca Arnalda, jako komisarza apostolskiego, i jego dwóch współbraci Henrykowi, królowi Kastylii, na terenie której przeprowadzić mieli reformę klasztorów franciszkanów i klarysek (Bullarium Franciscanum VI, n. 1297, s. 520; L. Wadding, Annales minorum..., t. 8, s. 332 i 333; Othon de Pavie, L'Aquitaine seraphique, Auch 1900, t. II, s. 53-54); trzecim, datowanym kilka dni później, do samych wysłanników, zawierającym wytyczne dotyczące misji; oraz czwartym, wysłanym w roku 1375, polecającym Arnaldowi wyznaczenie Bernarda z Garison na stanowisko lektora w Tuluzie (L. Wadding, Annales minorum..., t. 8, s. 389 ; Othon de Pavie, dz. cyt., t. II, s. 57).

${ }^{14}$ Wydanie tekstu w: Marian Michalczyk, Une Compilation Parisienne des sources primitives franciscaines. Paris Nationale, ms. lat. 12707, „Archivum Franciscanum Historicum" 74:1981, 323b, s. 88-138.

${ }^{15}$ Maria Teresa Dolso, La Chronica XXIV Generalium. Il difficile percorso dell'unità nella storia francescana, Padova 2003, s. 46. 
Kompilacyjny charakter Kroniki jest powodem, dla którego do niedawna odmawiano jej autonomicznego znaczenia. O wartości utworu stanowić miało jedynie zgromadzenie wielu obecnie zaginionych przekazów i szczegółowych informacji skądinąd nieznanych ${ }^{16}$. Istotnie autor, którego założeniem jest spisanie wszystkich godnych zapamiętania wydarzeń w historii zakonu ${ }^{17}$, gromadzi materiał korzystając $\mathrm{z}$ wielu źródeł ${ }^{18}$. Sięga m.in. do Kroniki czternastu lub piętnastu generałów Bernarda z Bessy, która staje się podstawą konstrukcyjną utworu i zapewnia podstawowe informacje dotyczące poszczególnych generalatów, a także do pełniącego podobną rolę Chronicon abbreviatum Peregryna z Bolonii. Korzysta także z pewnością z żywotów św. Franciszka i innych świętych, ze szczególnym uwzględnieniem Tractatus de miraculis, który stał się podstawą połowy przytaczanych w tekście cudów. W Kronice znaleźć można również ślady Legendae trium sociorum i skompilowanego z nią Anonima $z$ Perugii oraz jeden fragment zapożyczony z utworu Historia occidentalis Jakuba z Vitry ${ }^{19}$.Spośród tekstów hagiograficznych jako materiał posłużyły Arnaldowi również pierwsza i siódma księga Liber de laudibus beati Francisci Bernarda z Bessy, których treść przejmuje bez zmian, ingerując jedynie w układ poszczególnych fragmentów. Autor sięgał także do dostępnych kompilacji, materiału, którego tradycja jest do prześledzenia najtrudniejsza. Oprócz bowiem fragmentów pochodzących ze zbiorów o szerszym zasięgu, jak np. Speculum perfectionis, czy Actus Beati Francisci, w tekście Kroniki odnaleźć można ślady trudnych do zidentyfikowania kompilacji zachowanych niekiedy tylko w jednym egzemplarzu. Utrudniony dostęp do nich i to, że stają się czasem pośrednim ogniwem między popularnymi tekstami a Kronika, często uniemożliwia określenie właściwego źródła. M. T. Dolso wskazuje m.in. na błędne zinterpretowanie przez wydawców Kroniki ${ }^{20}$ fragmentów, które ich zdaniem zaczerpnięte zostały bezpośrednio z dzieła Angelo Clareno Historia septem tribulationum oraz z Dicta fratris Leonis ${ }^{21}$. Do-

${ }^{16}$ Zob. John R. H. Moorman, A History of the Franciscan Order: From Its Origins to the Year 1517, Oxford 1968, s. 396; B. Roest, dz. cyt., s. 38. Podobnie wypowiada się Stanislao da Campagnola, dla którego głównymi atutami kroniki są obszerość i szczegółowość (Le origini francescane come problema storiografico, Perugia 1974, s. 57-58).

17 „... notabilia bona et mala dispersa repperi...” (Cron. XXIV Gen., s. 1).

18 Dla szczegółowego omówienia źródeł wykorzystanych w Kronice odsyłam do M.T. Dolso, La Chronica XXIV Generalium. Il difficile percorso ..., s. 257-382.

${ }^{19}$ M. T. Dolso zwraca uwagę na sposób zaadoptowania fragmentu Legendy i Historia occidentalis, tamże, s. 316-317.

${ }^{20}$ Chron. XXIV Gen., s. IX-XI.

${ }^{21}$ M . T. Dolso, La Chronica XXIV Generalium. Il difficile percorso ..., s. 261-265. 
piero pogłębiona analiza wykazała, że ich treść do Kroniki dotarła za pośrednictwem znanych kompilacji. $\mathrm{Z}$ pewnością zatem pozostają do odkrycia związki tekstu z kompilacjami mniej znanymi. Autor korzysta również z dokumentów zakonnych, które przynajmniej częściowo znał bezpośrednio $\mathrm{z}$ archiwów, dzięki czemu niekiedy przekazuje nieznane skądinąd informacje. Jest na przykład jedynym źródłem, które wspomina o istnieniu listu papieża Aleksandra IV do biskupa Genui z roku 1254 zawierającego potwierdzenie stygmatów św. Franciszka.

Zbiór fragmentów pochodzących z różnych źródeł nie jest jednak zaledwie ich czysto mechanicznym zlepkiem. Tak jak kronika w ogóle doznała w średniowieczu pewnej nobilitacji i z chronologicznego spisu wydarzeń stała się odzwierciedleniem połączonego w logiczną całość obrazu świata ${ }^{22}$, tak też Kronika dwudziestu czterech generałów jest przykładem spójności tego rodzaju piśmiennictwa. Inwencja autora polega w niej nie tylko na wyborze i odpowiednim rozmieszczeniu fragmentów zaczerpniętych z dostępnych tekstów, lecz także na wyborze odpowiednich źródeł ${ }^{23}$, skolacjonowaniu różnych wersji opisywanych zdarzeń i wyjaśnieniu fragmentów, którym brak spójności ${ }^{24}$, a co najistotniejsze i wykraczające poza sam sposób potraktowania materiału, jego wizja historii zakonu jest przemyślana i jednorodna. Przede wszystkim powstanie zgromadzenia i jego historia są z punktu widzenia Arnalda z Sarrant efektem woli Boga, co czyni rozwój zakonu z gruntu pozytywnym ${ }^{25}$, a wszelkie negatywne wydarzenia pozwala uznać za próbę, której Bóg poddaje zakonników, lub też przenieść je poza obręb zakonu, odwołując się do działania demonów ${ }^{26}$. Zamysł ukierunkowany jest na podkreślenie jedności instytucji z założeniami św. Franciszka i ukazanie jego akceptacji dla zmian w kierunku klerykalizacji i instytucjonalizacji ${ }^{27}$, a także wagi jedności zakonu w ogóle. Uwidacznia się to w zestawieniu pozytywnej historii zakonu, w której autor stara się pogodzić wszelkie niespójności ${ }^{28}$, z symbolem wewnętrznego rozłamu, jakim była postać brata Eliasza z Kortony. Tradycja rękopiśmienna Kroniki w Europie Zachodniej zdaniem M. T. Dolso potwierdza, że również odbiorcy tekstu

${ }^{22}$ Henri de Lubac, Medieval Exegesis: The Four Senses of Scripture, t. 1, s. 43.

${ }^{23}$ M. T. Dolso, La Chronica XXIV Generalium. Il difficile percorso ..., s. 328.

24 Tamże, s. 72.

25 Tamże, s. 270.

${ }^{26}$ Chron. XXIV Gen., s. 27-29, 299-300, 381, 301; M. T. Dolso, La Chronica XXIV Generalium. Il difficile percorso ..., s. 50-53.

${ }^{27}$ M. T. Dolso, La Chronica XXIV Generalium. Il difficile percorso ..., s. 300-302.

28 Tamże, s. 98. 
traktowali go jako całość ${ }^{29}$. Przekazy zachowują strukturę z reguły nie wyodrębniając poszczególnych części (wyjątek stanowi kodeks zachowany w archiwum generalnym franciszkanów w Rzymie, który zawiera wyłącznie zebrane z tekstu Kroniki fragmenty annalistyczne).

\section{Przekazy rękopiśmienne Kroniki}

Do tej pory w literaturze przedmiotu funkcjonuje szesnaście kodeksów zawierających tekst Kroniki. Do edycji wydanej pod koniec XIX wieku, wykorzystano trzynaście z nich ${ }^{30}$ :

1. Assisi, Biblioteca Comunale, msc. 329 - koniec XIV w., pochodzący z klasztoru braci mniejszych w Asyżu,

2. Bologna, klasztor św. Antoniego, bez sygn. - 1453 r., pochodzący z klasztory obserwantów św. Annunciaty w Parmie,

3. Firenze, Biblioteca Riccardiana, cod. 279 - przełom XIV i XV w.,

4. Firenze, Biblioteca Laurenziana, cod. 53 - druga połowa XV w. (prawdopodobnie 1473 r.),

5. Milano, ..., - przełom XIV i XV w.,pochodzący z biblioteki klasztoru franciszkanów reformatów pod wezwaniem św. Piotra Apostoła w Rezzato,

6. Napoli, Biblioteca Nazionale, cod. VIII.C.7 Manoscritti - XV w.,

7. Roma, Biblioteca Angelica, lat. 1756 - przełom XIV i XV w., pochodzący z klasztoru Santa Maria degli Angeli w Asyżu,

8. Siena, klasztor obserwantów San Bernardino, bez sygn. - 1451 r.,

9. Siena, klasztor franciszkanów obserwantów, -1503 r., przekład na język włoski,

10. Trento, klasztor św. Bernardyna franciszkanów reformatów, G.XIV.21 - XVII w.,

11. Wien, Österreichische Nationalbibliothek, Cod. 3417 - 1470 r., oraz dziś zaginione, a podczas przygotowywania redakcji należące do:

12. klasztoru obserwantów św. Annunciaty w Parmie, bez sygn. - XV w,

13. biblioteki konwentu franciszkanów reformatów przy św. Marii od Aniołów w Halle (sygn. P.37.F) i podczas wojny prawdopodobnie przetransportowany do Innsbruku ${ }^{31}-1491 \mathrm{r}$.,

${ }^{29}$ M. T. Dolso, Un nuovo manoscritto della «Chronica XXIV generalium Ordinis Minorum»: il codice 142 della Bibliothèque municipale di Strasburgo, „Franciscana” 3, Assisi 2001, s. 208-209.

${ }^{30}$ Zob. Chron. XXIV Gen., s. XIII-XXV .

${ }^{31}$ M. T. Dolso, Un nuovo manoscritto ..., s. 203, przyp. 25. 
14. Biblioteki Uniwersytetu Lwowskiego ${ }^{32}$, sygn. I.G.17 - koniec XV w.

Do edycji nie weszły natomiast opisane później rękopisy:

15. Dublin, biblioteka klasztoru franciszkanów, bez sygn. - XV w. ${ }^{33}$, wyrózniający się stosunkowo bogatym zdobnictwem,

16. Strasbourg, Bibliothèque municipale, sygn. $142-14999^{34}$,

17. Roma, Archiwum Generalne Braci Mniejszych, sygn. A.17 - XV w.,

Na szczególną uwagę i bardziej drobiazgowe omówienie zasługuje posiadający polską proweniencję egzemplarz strasburski ${ }^{35}$. Jest to kodeks papierowy o wymiarach $10 \times 17 \mathrm{~cm}$, składający się z $284 \mathrm{k}$., spisany najprawdopodobniej jedną reką, pismem pośpiesznym i na ogół trudnym do odczytania. Tekst zorganizowany jest w jednej kolumnie i uporządkowany dzięki rubrykowanym tytułom rozdziałów i paragrafom oraz umieszczonym na marginesach kluczowym słowom, ułatwiającym dostęp do tekstu. Poszczególne generalaty, poczynając od Gonsalwa z Hiszpanii, zostały zaznaczone na niebiesko. Kodeks trafił do biblioteki municypalnej w Strasburgu w 1871 r., przekazany przez norymberczyka Siegmunda Pickerta ${ }^{36}$. O polskiej proweniencji świadczy explicit wymieniający nazwisko kopisty -Nicodema de Thulyszkow (prawdopodonie mowa o Tuliszkowie w Wielkopolsce) oraz datę powstania rękopisu, czyli rok $1499^{37}$. Kodeks, oprócz stanowącej jego główną część Kroniki (k. 23r-255v), zawiera również kilka krótkich tekstów: De indulgentia sancte gracie et de Portiuncola $(\mathrm{k} .1 \mathrm{v}-11 \mathrm{v})$; De beato Bernardino nostre regule riformatore (k. 256r), De beato Capistrano socio sancti Bernardini (k. 256r); In provincia opulentissimi regni Polonie (k. 257v); Ista adhuc pertinent ad vitam supradicti patris ubi (crux?) stat quod sequitur (k. 258v); Hec extracta sunt de Conformitatibus sancti patris Francisci (k. 259r); Loca fratrum debent paupercula [esse] et quis modus suscipiendi ea (k. 260r); Consilia demonii contra fratres (k. 261r); Demones fugan-

${ }^{32}$ M. T. Dolso nie udało się stwierdzić, czy rękopis znajduje się nadal we Lwowie. Do Biblioteki Narodowej wpłynęło 130 rękopisów pochodzących z Biblioteki Uniwersytetu Lwowskiego, m.in ponad 20 powstałych do I poł. XVI w., brak jednak wśród nich Kroniki.

33 Clément Schmitt, Manuscrits de la „Franciscan Library” de Killiney, AFH 57:1964, s. $173-174$.

34 Tamże.

35 Cały opis podaję za M. T. Dolso, Un nuovo manoscritto ..., s. 191-210.

${ }^{36}$ Zob. nota proweniencyjna na k. $1 \mathrm{r}$.

$37, \ldots$ hoc opus Cronicarum fratrum minorum est scriptum et finitum per me fratrem Nicodemum de Thulyszkow eiusdem ordinis immeritum. Ipso die sancte Crucis inventionis anno nostre salutis milesimo quadringentesimo nonagesimo nono ..." (k. 255v). 
tur de loci termino dicta oratione: Visita quaesimus Domine. In completorio (k. 261v); Fratres manifesta necessitate non teneantur ieiunio corporali (k. 263r); Nota tempore interdicti quomodo fratres se habeant (k. 263v); Historia lamentabilis admodum super devastacione civitatis elegantissime Constantinopolitane que fuit alter selus [!] Iudei ex dira occisione Grecorum facta in crastino sancti Bartholomei apostoli anno Domini 1453 (k. 264v-283r) ${ }^{38}$.

Do powyższej listy dodać można dwa kolejne przekazy Kroniki, znajdujace się w Bibliotece Narodowej ${ }^{39}$. Czas ich powstania dzieli zaledwie dwanaście lat, pochodzą też z tego samego środowiska - z należących do najstarszych w Polsce klasztorów bernardyńskich w Samborze i Kole.

\section{Rękopis BN 8084 II}

Pierwszym spośród wymienionych rękopisów jest kodeks papierowy o wymiarach $21,5 \times 16,5 \mathrm{~cm}$, złożony z 272 kart. Spisany został przez Baptystę Litwina ${ }^{40} \mathrm{w}$ roku 1491 i przekazany w 1511 przez Aleksego z Bobrek ${ }^{41}$ do klasztoru w Samborze, ośrodka, który miał być narzędziem w szerzeniu wiary katolickiej na wschodzie i dążeniu do skonsolidowania królestwa ${ }^{42}$. Do Biblioteki Narodowej, w której przechowywany jest obecnie pod sygnaturą 8084 II, dotarł za pośrednictwem Biblioteki Ordynacji Krasińskich ${ }^{43}$. Oprawiony został w deskę obciągniętą brązową skórą, tłoczoną radłem we wzory floraturowe wokół przekreślonego skośnie lustra zdobionego floraturowymi stemplami w identyczny sposób na obu okładkach. Na przedniej okładce zachowały się ponadto dwie zdobione metalowe klamerki, na tylnej natomiast fragmenty skórzanych pasków przytwierdzonych do deski trzema metalowymi sztyftami każdy. Blok książki wiąże pięć podwójnych zwięzów.

${ }^{38}$ Zawartość za M. T. Dolso, Un nuovo manoscritto ..., s. 201-202.

${ }^{39}$ Cf. Jerzy Kaliszuk, Mendicant Books and Libraries on South East Lands of the Polish Kingdom in the $15^{\text {th }}$ and Early $16^{\text {th }}$ Century - the Franciscans Observant Example, „Quaestiones Medii Aevi Novae” 15:2010, s. 157-158.

${ }^{40}$ W publikacji Józefa Kachela (Bernardyni 1453-2003, Warta 2004) brak informacji na temat kopisty. Zob. kolofon BN 8084, f. 260 v; Kopiści i kolofony rękopisów średniowiecznych ze zbiorów polskich, t. I: Biblioteki Warszawy, red. Edward Potkowski, Warszawa 1993, s. 20.

${ }^{41}$ Aleksy z Bobrek (1458 - non ante 1511) - mistrz nowicjatu w klasztorach w Krakowie (1499), Samborze (1501) i Warszawie (1503). Zmarł w Samborze po 1511 r. (zob. K. Kantak, Bernardyni Polscy. T. 1: 1453-1572, Lwów 1933, s. 88).

42 Małgorzata Maciszewska, Klasztor bernardyński $w$ spoteczeństwie polskim 1453-1530, Warszawa 2001, s. 70.

${ }^{43}$ Poprzednie sygnatury: BOK 3, akc. 11695. Sygnatura mikrofilmu: mf. 99182. 
Składki to zazwyczaj seksterniony (II-XVII, XIX, XX, XXII), występuje również kilka septernionów: I, XVIII i XXI. Do pierwszej składki dołączono ponadto pergaminową kartę ochronną. Po środku każdej składki znajdują się pergaminowe wszycia w większości pokryte tekstem (wszycia niezawierające tekstu występują wyłącznie w składkach XII, XVI, XVII, XVIII). Na początku dziesiątej składki dołączono fragment karty zawierający uzupełnienie tekstu. Ostatnia karta jest luźna.

Analiza znaków wodnych przedstawia się następująco:

1. Głowa wołu z krzyżem między rogami, oplecionym wężem - znak podobny do: Piekosiński 1090 (1484 r.) - karty: 40, 42, 46, 49, 51, 78, 85.

2. Głowa wołu z krzyżem między rogami, oplecionym wężem - znak podobny do Briquet 15381 (m.in. dla Poznania lata 1493-1520, dla Rosji 1481-1511) i Piekosiński 1093 (1486 r.) lub Piekosiński 1096 (1496 r.) - karty: 5, 6, 11, 12, 15, 28, 93, 150, 151, 156, 158, 159, 161, 163, 165, 172, 180, 189, 192, 194, 196, 206, 207, 209, 211, 214, 216, 222, 224, 225, 228, 233, 239, 242, 243, 246, 256, 258, 260, 263.

3. Waga o trójkątnych szalach wpisana w okrąg - znak podobny do Briquet 2448 (1453 r.) - karty: 55, 57, 58, 60, 63, 65, 67, 69, 70, 72, 74, $77,80,83,86$.

4. Głowa wołu z krzyżem między rogami, oplecionym wężem - znak podobny do Briquet 15375 (1492 r.) i Piekosiński 1094 (1489 r.) karty: 129, 134, 136, 137, 140, 143, 202, 203.

W kodeksie daje się wyróżnić pismo wielu rąk, spośród których jedna zdecydowanie dominuje i pojawia się w kilku partiach tekstu.

Poza poprawkami i uzupełnieniami tekstu głównego poczynionymi w większości przypadków prawdopodobnie przez skrybę (k. 43v, 114v, $144 \mathrm{v}, 147 \mathrm{v}, 173 \mathrm{v}, 233 \mathrm{v}, 236 \mathrm{r}$ ) i zamieszczonymi na marginesach krótkimi streszczeniami poszczególnych fragmentów, które zapisane zostały różnymi rękami współczesnymi głównemu tekstowi (k. 9r, 9v, 13v, 41r, $42 \mathrm{r}, 121 \mathrm{v}, 122 \mathrm{v}, 123 \mathrm{r}, 123 \mathrm{v}, 130 \mathrm{v}, 131 \mathrm{r}, 131 \mathrm{v}, 136 \mathrm{r}, 136 \mathrm{v}, 138 \mathrm{r}, 138 \mathrm{v}$, 139r, 139v, 140r, 141r, 160v, 170v, 178r, 179v, 181v, 216r, 224v, 230v) zauważyć można kilka uwag zanotowanych ręką późniejszą (k. 2v: glosa do Exemplum de quadragesima benedictorum, 237r i 237v: glosy do fragmentu Kroniki dotyczącego listu królowej Sancii do zakonu i ustanowienia mszy za jej duszę). Tą samą ręką zapisano na marginesach tłumaczenia niektórych zwrotów na język polski (np. na k. 8v: „hendoga” i „Abych czy tysz wskaszal inszy rzeczy”). Część marginaliów, 
przede wszystkim te zapisane rubro, należy prawdopodobnie do zamierzonego ordinatio textus. Ponadto, poczynając od k. 9v, pojawia się pagina currens, która powraca następnie na k. $270 \mathrm{v}$ w De conformitatibus. Niekiedy umieszczono na marginesie rączki (k. 29r, 148v, 170v, 195r, 184v) lub odpowiadający im zwrot nota bene (k. 154r, 157r.). Na każdej karcie verso zawierającej Kronikę na górnym marginesie zapisano cyframi rzymskimi numer karty. Całość kodeksu ma późniejszą foliację.

Układ tekstu zorganizowany jest za pomocą rubrykowanych tytułów oraz niebieskich i czerwonych inicjałów o ozdobnym kształcie, urozmaiconych często podwójnymi liniami, guzami, wąsami i uwypukleniem brzuszków. Na kartach $224 \mathrm{v}$ i $229 \mathrm{v}$ pozostawiono puste miejsca na inicjały. Na czerwono bądź niebiesko oznaczono również poszczególne paragrafy, a czerwoną linią przekreślono część liter i znaków interpunkcyjnych oraz popełnione przez kopistę błędy (100r i 119r). Rubro zostały również zapisane żywe paginy i część marginaliów (w tym rączki na k. 148 r, 184v i 195r oraz zapiski na k. 122r i 123r). Większość miniatur została wycięta (k. 40, 88, 108, 113, 125, 132, 143, 169, 181, 185, 190, 197, 201, 208, 219, 250, 253, 254, 256, 260). Zachowały się jedynie cztery ilustracje przedstawiające: twarz franciszkanina na czerwonym tle w białe floraturowe wzory w potrójnej seledynowo-żółtej ramce (k. 127r), postać franciszkanina na podobnym tle w zielono-żółtej ramce (k. 137v), w zielonej ramce $(\mathrm{k} .147 \mathrm{r})$ i na zielonym tle w niebieskiej ramce $(\mathrm{k}$. 247r). Do kart: 40, 52, 61, 65, 69, 85, 104, 108, 113, 125, 127, 132, 137, 143, 147, 169, 181, 186, 189, 197, 201, 209, 220, 224, 229 doklejone zostały skórzane indeksy introligatorskie. Na tylnej wyklejce (k. 273r) znajduje się rycina przedstawiająca świętych Kryspina i Kryspiniana w warsztacie $^{44}$.

Na grzbiecie, u góry, naklejono kartkę z datą i tytułem: „1491 Kronika zakonu św. Franciszka”, poniżej pionowo kartkę z sygnaturą: „2230”. Na k. 2r nad tekstem, u góry strony, zapisek: „Istas conformitates seu libellum istum misit frater Alexius de Bobrca pro loco Samborie[n]si 1511". Na przedniej wyklejce, u góry, zamieszczone zostały kolejne oznaczenia: „43” oraz „J, III 2”, po środku pieczęć Biblioteki Ordynacji Krasińskich. Obcięto prawy dolny róg karty 1r, w którym mogła znajdować się pieczęć biblioteczna.

${ }^{44}$ Waldemar Deluga, Katalog XV-wiecznych rycin z kolekcji polskich, Kraków 2005, s. 54 , poz. 57. 
Zawartość kodeksu przedstawia się następująco:

1. k. 1r: Spominki minorytów samborskich ${ }^{45}$

2. k. $1 \mathrm{v}:$ De libro conformitatum

Beatus Franciscus et eius ordo declarata venturus et praeclara fienda per ipsum ordinem per abbatem Ioachim ... $><\ldots$ corporis ... suffragante suppetui ... (częśś nieczytelna).

3. k. 2r-4v: Exemplum de quadragesima benedictorum

Quidam frater simplex novicius tempore quo fuit pater Iohannes Capistranus Cracovie ... $><\ldots$ Et sic ille frater invenit se lacrimantem et ad se veniens audivit pulsum ad primam, surgensque ivit ad primam et postea omnia fratribus narravit sicut sibi contigerat. Ad laudem domini nostri Jesu Christi.

4. k. 5r-6v: Exemplum de missa conventuali

Quidam frater iam post matutinum et post orationem posuerat se dormitum. Tunc apparuit ei angelus ... $><$.. frater ille fuit calefactus et in illa calefactione perseveravit usque in finem. De qua misericordia dei omnipotentis et gratia virginis Marie sit laus deo et honor in secula seculorum. Amen.

5. k. 6v-7r: De sompnolencia fratrum in divino officio

Quidam frater veniens ad officium matutinale talem visionem habuit ... $><\ldots$ Et illi fratres cum tedio et acedia et cum sompnolencia id officium compleverunt, etc.

6. k. 7r-8r: De devote dicentibus divinum officium

Quidam frater post orationem ... $><\ldots$ dicens ei: fac similiter et salvus eris.

7. k. 8r-8v: Quomodo per vanas et malas cogitationes homo efficitur apostata coram deo exemplum

Quodam tempore quidam frater fuit ductus a quodam sene ad quendam locum ... > <.. et reduxit contra eum ad locum suum, etc.

8. k. 8v-11r: Exemplum de conformitatibus

${ }^{45}$ MPH III, s. 252. Spominki zawierają notatki dotyczące wydarzeń z lat 1492 (śmierć Kazimierza Jagiellończyka), 1501 (sukcesja Aleksandra), 1471 (koronacja Władysława Jagiellończyka na króla Czech), kariery duchownej Fryderyka Jagiellończyka (dla której podaje się tylko jedną datę: 1493, czyli datę objęcia arcybiskupstwa gnieźnieńskiego i prymasostwa), 1455 (ślub Kazimierza Jagiellończyka). Najpóźniejsze wzmiankowane wydarzenie dotyczy roku 1501. Brak informacji na temat śmierci Aleksandra Jagiellończyka w roku 1506 wyznacza zapewne datę post quem non dla tej konkretnej karty. Powyższe zapiski, spisane jedną ręką tylko na pierwszej stronie rękopisu, dotyczą najistotniejszych wydarzeń współczesnych początkowi istnienia bernardynów na ziemiach polskich i wymieniają osoby ściśle z zakonem związane. To m.in. na prośbę Kazimierza Jagiellończyka do Krakowa przybył Jan Kapistran, a dążenia króla sprzyjały ekspansji braci. 
Erat quidam frater qui post orationem matutinalem finita oratione se deponere volens ... $><\ldots$ Et illi fratres dixerunt omnia de illo fratre prout habuit visionem quando fuit inobediens et impatiens et sic de aliis prout supra notatum est, etc.

9. 11r-13r: Aliud exemplum de temptationibus

Quidam frater minor cum quodam tempore sero posuerat se ad dormiendum venit ad eum Sathan in forma Ethiopis ... $><\ldots$ et hiis expletis frater dixit ad eum: Jam tibi de licentia recedendi. Et sic discessit $a b$ eo, etc.

10. k. 13r-13v: De Marionali excerptum

Unde quidam predicator dicebat, quod de eis verificatum est illud Jeremie XIII .. $><\ldots$ asserens se pro prenominato episcopo hanc visionem non sine magna lacrimarum effusione narrante propriis auribus audisse etc.

11. k. 14r: pusta.

12. $14 \mathrm{v}$ : Hec de conformitatibus

Francisci officii et historiae compositationes plures fuere. Papa Gregorius IX fecit prosam ... $><\ldots$ Et erant in summa septingenti et quadraginta novem anni et ducenti septuaginta tres dies, etc.

13. k. 15r-36r: Indeks zawartości Kroniki.

Adrianus papa quintus quondam vocatus dominus Otholanus Laudinensis singularis pater ordinis tempore IX generalis, folio 142 ... $><$... Zataranensis Anthonius vir scolasticus de genere militari quomodo exarserat in amorem cuiusdam domine tempora VII generalis folio 133.

14. k. 36v: De conformitatibus

Sed hic oritur dubium, quia regula debet fratri Francisco esse obediendum, etc. ... $><\ldots$ conformitate 9 sub littera $t^{46}$.

15. k. 37-38: karty wycięte

16. k. 40r-260v: Arnaldus de Sarrano, Cronica XXIV Generalium

In nomine Domini incipiunt cronicae fratrum minorum IHS. [Prologus:] Quoniam preteritorum narracio utilis est ad erudicionem presencium et futurorum cautelam ... in sequenti volumine collegi. [k. $1 \mathrm{r}$ - Textus:] Primus ordinis generalis fratrum minorum gloriosus pater noster s. Franciscus extitit ... $><$... Anno domini 1374 idem dominus protector ex hac vita migravit. Explicit opus anno domini 1491. Frater Babtista Lythwanus etc. finivit etc. Amen.

${ }^{46}$ Zob.: Bartholomeus de Pisa, De conformitate vitae beati Francisci ad vitam domini Jesu, „Analecta Franciscana”, t. IV, Quaracchi 1906, s. 369-457. 
17. k. 261r-269r: Sacrum commercium ${ }^{47}$

Incipit comercium beati Francisci cum domina Paupertate. [Prologus:] Beati pauperes spiritu, etc. Inter ceteras preclaras et precipuas virtutes ... ut posset pervenire ad eam, cui deus tradidit claves regni celorum. [k. 261r - Textus:] Beatus Franciscus interrogat de paupertate ... $><\ldots$ Qui cum patre et filio et spiritu sancto vivit et regnat per omnia secula seculorum amen. Explicit Commercium Paupertatis, quod composuit frater Iohannes de Parma vii generalis, ut habetur folio 110.

18. k. 269v-270v: Loca fratrum debent esse paupercula et modus suscipiendi

Cum enim beatus Franciscus sepe fratribus sermonem faceret de paupertate ingerebat eis hoc Ewangelicum ... $><$... excitantes a sompno ad cellam euntes dicti fratris clausuram intactam sed alia ipsius ammota invenerunt et combusta prout inspexaverunt ipsi fratres etc.

19. k. 270v-272v: Quam vero multum displicent beato Francisco mutaciones locorumet edificia sumptuosa

In quadam visione ipse ostendit post suam mortem ... $><\ldots$ Sed quia complevi penitenciam meam modo ad paradisum pergo de tercio de quo michi imposuisti scias quod bene quinque milia animarum.

Bibliografia: Spominki Minorytów Samborskich, „Monumenta Poloniae Historica”, t. III, Lwów 1878, s. 252; Franciszek Pułaski, Opis 815 rękopisów Biblioteki ord. Krasińskich, Warszawa 1915, s. 56; Kopiści i kolofony rękopisów średniowiecznych ze zbiorów polskich, tom I, Biblioteki Warszawy, pod red. Edwarda Potkowskiego (z serii: Manuscripta Medii Aevi Polona. Polska Pisząca w Średniowieczu), Warszawa 1993, s. 20; Agnieszka Jabłonka, Średniowieczne rękopisy z Biblioteki Krasińskich, „Biuletyn Informacyjny Biblioteki Narodowej” 2002 nr 4, s. 38; Waldemar Deluga, Katalog XV-wiecznych rycin z kolekcji polskich, Kraków 2005, s. 54, poz. 57; Jerzy Kaliszuk, Mendicant Books and Libraries on South East Lands of the Polish Kingdom in the 15 th and Early 16 $6^{\text {th }}$ Century - the Franciscans Observant Example, „Quaestiones Medii Aevi Novae”, 15:2010, s. 157-158.

47 Wyd.: Sacrum commercium sancti Francisci cum domina Paupertate, „Medioevo Francescano. Testi 1", Assisi 1990. 


\section{Rękopis BN BOZ 1114}

Liczacy 162 karty kodeks o wymiarach $21,5 \times 15,5 \mathrm{~cm}$ w roku $1503 \mathrm{spi}-$ sał pochodzący z Konina brat Izydor. Wiemy o nim jedynie, że pełnił funkcję kaznodziei w klasztorze św. Anny w Warszawie ${ }^{48}$. Egzemplarz przyznany mu dożywotnio w używanie przekazany miał być następnie bibliotece klasztoru kolskiego. O tym, że faktycznie się tam znalazł świadczy nota proweniencyjna na karcie Ir. Potwierdza to również katalog biblioteki bernardynów w Kole ${ }^{49}$. Kodeks znajdował się w zbiorach Ordynacji Zamojskiej a do Biblioteki Narodowej został włączony w 1959 roku, gdy do kraju powróciły zbiory wywiezione przez Niemców w czasie II wojny światowej. Przechowywany jest tam pod sygnaturą BOZ $1114^{50}$. Zachowana do dziś średniowieczna oprawa kodeksu została wykonana $\mathrm{z}$ desek obciągniętych ciemną skórą. Zarówno przednią jak i tylną okładkę ozdobiono w zwierciadle ślepymi tłoczeniami w kształcie korony z gotyckimi napisami IHS i Maria. Do kodeksu przymocowana była katena, o czym świadczy dziś jedynie odłamany kawałek deski z tylnej okładki. Zachowało się kilka guzów, brak natomiast metalowych okuć, których ślady są widoczne. Kodeks spinają dwa skórzane zapięcia. Być może jego grzbiet wzmacniały kapitałki, których obecnie brak.

Kodeks składa się z trzynastu pełnych poszytów, z których pierwsze sześć to seksterniony, kolejne dwa to septerniony. Do ostatniej, luźnej, karty doklejono początkowo dwie kolejne. Układ składek możemy kontrolować na podstawie częściowo ocalałych reklamantów. Zachowały się one bez uszczerbku na kartach 113 i 131, a częściowo obcięte przez introligatora na kartach: 35, 59, 107, 145. Kolejnym zewnętrznym dowodem na prawidłowy układ tekstu jest średniowieczna foliacja zapisana cyframi arabskimi na kartach od 1 do 154 . Karty 155-162 zostały oznaczone ręką późniejszą. Brak numeracji współczesnej.

\section{Znaki wodne:}

1. Głowa wołu z krzyżem między rogami, oplecionym wężem - znak podobny do Picard 140/141 (1482, 1483), Briquet 15374 (1488). Podobny także do Briquet 15369 (1482) i Lichatchew 3891 - karty: 2, $9,41,42,51,56,63,64,65,66,67,68,77,78,87,88,91,92,98,100$,

48 J. Kachel, Bernardyni 1453-2003, t. 2, s. 248.

${ }^{49}$ K. Kantak, Bernardyni polscy, t. II, s. XXX, wymienia kodeks zawierający katalog biblioteki bernardynów kolskich (Series librorum in conventu Colensi 1860) przechowywany we Włocławku, Archiwum Kapitulne, sygn. 52.

${ }^{50}$ Dawna sygnatura: akc. BOZ 1114. Mikrofilm znajduje się pod sygnaturą: mf. 1035. 
$103,105,113,114,124,125,126,127,134,135,138,139,142,143$, $148,149,152,153,156,157$.

2. Głowa wołu z trójkątem na pręcie w pysku i różą na pręcie, umieszczonym między rogami - znak podobny do Picard 755 (1474) i Briquet 14883 (1476/1481) - karty: III, 5, 6, 11, 12, 14, 16, 19, 21, 25, 26, 28, $31,33,34,36,40,43,47,50,57,60,61,70,71,73,74,81,82,86,93$, 97, 106, 108, 110, 117, 119, 160.

Tekst główny, czyli cała kronika (k. 1r-160v), spisany został przez jednego skrybę, wspomnianego wyżej Izydora z Konina. Dukt pisma jest dość łagodny i mało charakterystyczny, przypominający bastardę. Na kartach 161v-162v znajduje się krótki tekst dotyczący użytkowania przez braci ozdobnych kielichów i monstrancji. Jego autorem, jak i skrybą jest wikariusz prowincji polskiej bernardynów, Jan Szklarek (Ioannes Vitreatoris $)^{51}$, ten sam, który w notce zamieszczonej u góry przedniej wyklejki przyznaje kodeks Izydorowi z Konina, a po jego śmierci klasztorowi w Kole. Pismo jego jest pośpieszną kurywą gotycką z licznymi skrótami, które dotyczą zwłaszcza oznaczeń ksiąg prawa kanonicznego. Według Kamila Kantaka tekst powstał ${ }^{52}$ podczas podróży, której celem była wizytacja poszczególnych klasztorów prowincji.

Rozplanowanie tekstu jest charakterystyczne dla późnego średniowiecza i przejawia się przede wszystkim w oznaczaniu poszczególnych paragrafów kolejnymi literami alfabetu i odpowiadającym im spisie treści na kartach $145 \mathrm{r}$ i v, zwięzłych opisach treści na marginesach, rubrykacji istotniejszych fragmentów. Poza tym kodeks zawiera niewiele glos. $\mathrm{Na} \mathrm{k.} \mathrm{1r} \mathrm{widnieje} \mathrm{obliczenie} \mathrm{wykonane} \mathrm{w} \mathrm{roku} \mathrm{1585,} \mathrm{na} \mathrm{k.} \mathrm{21v} \mathrm{kilka} \mathrm{do-}$ pisków ręką skryby. Na kartach $122 \mathrm{v}$ i $123 \mathrm{r}$ imię Bernardus przeprawione zostało w czterech miejscach na Raymundus.

Pismo i ozdoby w tekście są dość proste i wykorzystują niezbyt skomplikowane motywy geometryczne i roślinne. Zastosowano przede wszystkim rubrykacje, tak w tekście głównym, jak i marginaliach, inicjały zaś zostały niekiedy dodatkowo ozdobione na zielono i niebiesko.

$\mathrm{Na}$ antefolium znajduje się pochodząca z XV wieku notka proweniencyjna: „Concessus liber iste ad usum patris Isidori de Konyn / predicatoris per me fratrem Johannem Vitreatoris pro tunc vicarium / po-

${ }^{51}$ Zob. m.in.: Polski Słownik Biograficzny 10, s. 485-487; Helena Friedberg, Rodzina Vitreatorów (Zasańskich) i jej związki z Uniwersytetem Krakowskim na przełomie XV i XVI w., „Biuletyn Biblioteki Jagiellońskiej”, 18:1968, nr 1, s. 21-25.

${ }^{52}$ K. Kantak, Sylwetki bernardynów poznańskich, Poznań 1934, s. 326-327. 
stea assignatur loco Colensi”. Z tego samego czasu pochodzą wpisy na postfolium, zawierające przede wszystkim fragmenty hymnów i sekwencji $^{53}$. Jeden z nich wymienia imię brata Tymoteusza z Grodziska (prawdopodobnie użytkownika lub właściciela kodeksu). Na k. IIIr zapisano ręką pochodzącą najprawdopodobniej z początku szesnastego wieku: „Loci Colens[is]”. Ponadto znajduje się w rękopisie kilka wpisów dziewiętnastowiecznych i pieczęcie Biblioteki Ordynacji Zamojskiej.

Na zawartość kodeksu składają się:

1. k. 1r-154r: Arnaldus de Sarrano, Cronica XXIV Generalium In nomine Domini. Amen. Incipit Cronica fratrum minorum. [Prologus:] Quoniam preteritorum narratio utilis est ad erudicionem presentium et futurorum cautelam ... Tempora primi generalis id est sancti Francisci. [k. 1r - Textus:] Primus itaque omnium generalium ministrorum fuit pater noster ... $><\ldots$ Eodem anno fuit postulatus ordinis protector dominus Guilhelmus tituli sancti Clementis presbiter Cardinalis Lemonicensis. Anno domini 1374 idem dominus protector ex hac vita migravit. [rubro:] Ad laudem et gloriam omnipotentis dei ac genitricis eius beatissime virginis Marie sanctissimique patris nostri sancti Francisci omniumque patrum sanctorum ordinis minorum opus hoc Cronicarum completum scriptumque est manu fratris Isidori de Conyn eiusdem ordinis minimi obsecrantis humiliter lectorem cum audientibus unum Ave Maria.

2. k. $154 \mathrm{v}-160 \mathrm{v}$ : Tabula operis

[rubro:] Incipit tabula huius operis in qua hoc advertendum est quod numerus significat quotas foliorum, littera vero alphabeti locum materie. - Abbas sancti Benedicti cum omnibus suis fratribus ordinem fratrum minorum est ingressus ... $><\ldots$ Ymago crucifixi fratres dissolutos in choro valde terruit $97 n$.

3. k. 160v-161r: Tabula super legendam Sancti Anthonii de Padua [rubro:] Tabula super legendam sancti Anthonii de Padua. - Abbas commendavit sanctum Anthonium 37 s ... $><$... ymago S. A. miraculose remansit $45 \mathrm{f}$.

4. k. 161v-162v: Johannes Vitreatoris, De calicibus

${ }^{53}$ M.in.: Sacerdos et pontifex et virtutum opifex, pastor bone; Sanctissima domina angelorum regina speculum sine macula; Salve sponsa Christi, lux forma; Sanguine proprio redemisti nos deus. Illuc et revehis vnde primus corruit Solve iu(?)benter viribus; Sanctorum meritis ... gaudia sangwine tuo redempti sumus deputati ut Consolator optime dulcis hospes anime; Salve sancte pater patriae lux Celorum Candor splenduit novum genus potentie: aque rubescunt idrie vinum que iussa fundere mutavit unda originem. 
De calicibus et monstranciis accipiendis non sum turbatus ... $><\ldots$ fuiterit opinio et avisamentum et incursum hostium quottidiana.

Bibliografia: Polski Słownik Biograficzny, t. 10 (odnośnie Jana Vitreatoris); Stownik polskich teologów katolickich (ad idem) pod red. Hieronima Eugeniusza Wyczawskiego, Warszawa 1982; Kopiści i kolofony rękopisów średniowiecznych ..., s. 25; Katalog wystawy rękopisów i druków wywiezionych przez hitlerowców do Niemiec, uratowanych przez Armię Czerwona i przekazanych Polsce przez Rzad Radziecki, Warszawa 1948, s. 17.

\section{Analiza porównawcza przekazów}

Analiza wariantów tekstu występujących w rękopisach BN 8084 i BN BOZ 1114 pokazuje wyraźnie związek tych przekazów z grupą nazwaną przez M. T. Dolso „północną" ${ }^{4}$, czyli z rękopisami pochodzącymi z Halle, Lwowa i Wiednia (przy czym omawiane kodeksy najbardziej są zgodne $\mathrm{z}$ dwoma ostatnimi) oraz rękopisem strasburskim ${ }^{55}$. Tam, gdzie rękopisy lwowski i wiedeński różnią się od pozostałych wykorzystanych do opracowania wydania, zazwyczaj występujące w nich warianty pokrywają się z tekstem kodeksów Biblioteki Narodowej. Mniej podobieństw zachodzi pomiędzy tymi rękopisami a kodeksem z Halle, nadal jednak można zauważyć wiele cech wspólnych.

Analiza wariantów znaczących, do których zaliczyć należy przede wszystkim pominięcie pewnych fragmentów, dopisanie innych, zmianę kolejności, a także różnice $\mathrm{w}$ podziale tekstu na tytuły i paragrafy, wygląda następująco ${ }^{56}$ :

\section{Strona Opis fragmentu wydania \\ s. $35-36$ \\ Pominięcie początkowego fragmentu Vitae fratris Bernardi, BN 8084 BOZ 1114 Stras. 142 dotyczącego przyłączenia się brata Bernarda do Franciszka. Tekst żywotu zaczyna się dopiero od zdania: Hic frater Bernardus de Quintavalle in}

${ }^{54}$ M. T. Dolso, Un nuovo manoscritto ..., s. 202-203.

${ }^{55}$ Strasbourg, Bibliothèque nationale et universitaire, 142.

56 Zestawienie wzoruję na M. T. Dolso, Un nuovo manoscritto ..., s. 195-199. Również z powyższego artykułu pochodzą dane dotyczące kodeksu straburskiego. 
suae conversationis principio ...

s. 38-40 Zamiana kolejności fragmen- + (k. 54v) + (k. 10r) + (k. 23r) tów. Tekst zaczynający się Pominięcie od słów: Cum vero beatus fragmentu

Franciscus Hispaniam ad visitandum reliquias ... następuje po fragmencie zatytułowanym: De eius contemplatione et humilitate et oboedientia.

s. $60 \quad$ W Vita fratris Iuniperi brak rozdziału Remedia contra carnis tentationes.

s. 61-62 W Vita fratris Iuniperi dwa następujące po sobie fragmenty, mianowicie: Qualiter intravit Viterbium nudus i Qualiter honores declinavit zostały umieszczone później, niż w wydaniu, przed: Qualiter nudus ivit Assisium sine femoralibus.

s. 64 W Vita fratris Iuniperi brak fragmentu zatytułowanego: Qualiter vidit manum in aere.

s. 72 W żywocie brata Leona w miejscu zatytułowanym: De zelo ad evangelicam paupertatem umieszczony został rozdział o skróconym tytule: De zelo paupertatis, zawierający jedynie dwa pierwsze wersy pełnego tekstu.

s. 73 Tamże brak rozdziału De quadam visione quam $+(\mathrm{k} .63 \mathrm{v})+(\mathrm{k} .16 \mathrm{v})+(\mathrm{k} .33 \mathrm{v})$ $+(\mathrm{k} .64 \mathrm{v})+(\mathrm{k} .17 \mathrm{v})+(\mathrm{k} .34 \mathrm{v}-$ $35 r$ ) habuit de obitu fratris Rufini.

s. $75 \quad$ W opisie żywota brata

$$
+(\mathrm{k} .65 \mathrm{r})+(\mathrm{k} .17 \mathrm{v})+(\mathrm{k} .34 \mathrm{v}-
$$

$+(\mathrm{k} .68 \mathrm{r})+(\mathrm{k} .20 \mathrm{r})+(\mathrm{k} .38 \mathrm{v})$

Na końcu Na końcu

fragmentu fragmentu

dodane dodane

zakończenie: zakończenie:

etc., ut in primo etc., prout

quinterno de supra folio

concha sive 9 usque ibi

cippo per ab officio

ordinem absolutus

usque ad fuit.

hanc locum.

$+(\mathrm{k} .68 \mathrm{r})+(\mathrm{k} .20 \mathrm{v})+(\mathrm{k} .38 \mathrm{v})$

Idziego (za generalatu

$+(\mathrm{k} .68 \mathrm{v})+(\mathrm{k} .20 \mathrm{v})$

św. Franciszka) po opisie jego pokory następuje podsumowanie: [...] et non ad ima volare quam qui se exaltat humiliabitur et qui se humiliat exaltabitur iuxta verbum Domini. 
s. 101-102 W Vita fratris Aegidii ostatni fragment: Qualiter mulier quaedam lac pro nutriendis filiis eius meritis impetravit zapisany został po łacinie, podczas gdy rękopisy włoskie przytaczają je w języku rodzimym (Lasciami iacere, se io non salisco in alto, non posso cadere).

s. 171-173 W Vita fratris Christophoris brakuje części cudów brata Krzysztofa.

s. 207-209 Pod koniec fragmentu poświęconego Franciszkowi brak dwóch części pośmiertnych cudów św. Franciszka od fragmentu De contractis curatis, gdzie zostały pominięte dwa ostatnie cuda do De vulneratum letaliter per sanctum mirabili liberato.

s. 211 We rozdziale poświęconym generalatowi Jana z Parmy brak części zdania dotyczącego przechowywania Ciała Chrystusa: [...] et inde, praesente populo aliquando $+(\mathrm{k} .79 \mathrm{v})+(\mathrm{k} .28 \mathrm{v})+(\mathrm{k} .51 \mathrm{v})$

Dimitte me Dimitte me iacere, quia iacere, quia si ascendo sinon [!] in alto ascendo in non potero alto non cadere. potero cadere.

$+(\mathrm{k} .108 \mathrm{r})+(\mathrm{k} .48 \mathrm{r})+(\mathrm{k} .86 \mathrm{r})$ Lacuna obejmuje większy fragment od De evomente clavum ferreum periculose antea eglutinum do końca żywota (czyli do początku żywota Agnieszki). Z tej części zostaje przytoczony tylko jeden cud, mianowicie De liberatis a periculo partus

(s. 168-173). $+(\mathrm{k} .124 \mathrm{v})$

$+(\mathrm{k} .125 \mathrm{r})+(\mathrm{k} .59 \mathrm{v})$ 
vel haberi non potest, funo

quo suspenditur impedito,

vel eo rupto non sine

scandalo cadit.

s. 211 We fragmencie poświęconym generalatowi Jana z Parmy brak opisu wylania Tybru.

s. 214 Brak fragmentu dotyczącego $+(\mathrm{k} .125 \mathrm{v})+(\mathrm{k} .59 \mathrm{v})$ rezygnacji Jana z Parmy z funkcji generała zakonu.

s. 221 Po wzmiance na temat dwóch braci, którzy ponieśli męczeńską śmierć z rąk Saracenów w Kataloni odsyłacz: Eorum passionem vide supra $52 b$.

s. 263 Modyfikacje zdania dotyczącego represji Krescentego $\begin{array}{r}+(\mathrm{k} .144 \mathrm{r}) \\ \text { Zdanie }\end{array}+\underset{\text { Zdanie }}{(\mathrm{k} .70 \mathrm{v})}+\underset{\text { Zdanie }}{(\mathrm{k} .123 \mathrm{v})}$ zakończone: zakończone: zakończone: z Jesi wobec ,secta fratrum”. (Wg wydania zdanie zakończone: [...] valenter exterminavit $\left.^{56}\right)$.

s. 274-275 W rozdziale poświęconym generalatowi Jana z Parmy został pominięty fragment mówiący o pobłogosławieniu chleba przez św. Klarę, który w innych przekazach pojawia się w tym miejscu po raz drugi, ${ }^{57}$.

s. 286 Brak krótkiego fragmentu dotyczącego miejsca pochówku brata Benedykta (w Arezzo).

s. 291 W rozdziale dotyczącym generalatu Jana z Parmy została zamieniona kolejno-

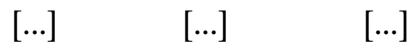
exterminavit extirpavit exterminavit et delevit. et delevit. et destruit $+(\mathrm{k} .147 \mathrm{v})+(\mathrm{k} .72 \mathrm{v})+(\mathrm{k} .126 \mathrm{v}-$ 127r) ść poszczególnych fragmentów (fragment zaczynający się od słów: Simile scribitur in Almania zamieszczony później niż w wydaniu).

s. 305-306 W rozdziale dotyczącym generalatu Jana z Parmy

$$
+(\mathrm{k} .151 \mathrm{v})
$$$$
+(\mathrm{k} .155 \mathrm{v})+(\mathrm{k} .76 \mathrm{r})+(\mathrm{k} .132-
$$

$$
+(\mathrm{k} .161 \mathrm{r})
$$

${ }^{57}$ Szczególną uwagę zwraca na to miejsce M. T. Dolso (w analizowanym przez nią rękopisie strasburskim zamiast słowa delevit użyte zostało destruit). Zob. M. T. Dolso, Un nuovo manoscritto ..., s. 197. 
brak opisu wizji na temat

hostii.

s. 306-307 Zamiana kolejności dwóch egzemplów opowiadających

$$
-\quad+(\text { k. 81) }
$$

o ukazaniu się Chrystusz

nowicjuszom, którzy chcieli

opuścić zakon (inc.: In pro-

vinciae Aquitaniae ... i inc.:

Quidam delicate nutritus ...).

s. 322 W tymże rozdziale brak

fragmentu zatytułowanego:

Qualiter quaedam mulier

consilio cuiusdam fratris

nominando Iesum diabolicas

illusiones evasit (jak zaznacza

M. T. Dolso jest to jednak

fragment pominięty w wielu

kodeksach, również włoskich $)^{58}+(\mathrm{k} .168 \mathrm{v})+(\mathrm{k}$. 86r $)+(\mathrm{k} .151 \mathrm{r})$

i został opisany już wcześniej

(str. 315).

s. 364 W rozdziale dotyczącym gene- $\quad+(\mathrm{k} .184 \mathrm{r}-\quad+(\mathrm{k} .97 \mathrm{v})+(\mathrm{k} .171 \mathrm{v}-$ ralatu Girolamo z Ascoli $184 \mathrm{v})$

dodany jest fragment zatytuło-

wany: Qualiter beatus Franciscus

maledixit fratri Iohanni de

Scotia ministro Bononie (jak

we wszystkich kodeksach

z grupy północnej).

s. 396-404 Brak większej części Meditatio- + (k. 196v)

nes fratris Rogerii.

s. $416 \quad$ W Vita fratris Mattei de

Aquasparta zdanie mówiące

o męczeństwie braci: In Prussia

frater Conradus et frater Voisilus

pro fide sacrum martyrium

zakończone: qui in Chetmno

iacent.

s. 416-417 W Vita fratris Mattei de

$+(\mathrm{k} .200 \mathrm{v})+(\mathrm{k} .111 \mathrm{r})+\mathrm{k} \cdot(191 \mathrm{v})$

Aquasparta brak fragmentu

Martirium fratris Philippi

s. 435 Dopisek, którego brak w po-

zostałych rękopisach: Quicum-

-+ (k. 111r)

Zamiast

Voisilus

Vosilinus.

que tria Pater noster ad

honorem Sanctae Trinitatis

et ipsius sancti Ludovici

cum firma fide dixerit quamcum-

${ }^{58}$ Po raz pierwszy to samo wydarzenie opisane w Cron. XXIV Gen., s. 182-183. 
que gratiam petierit a Deo meritis

beati Ludovici impetrabit. Sic

ipse sanctus cuidam civi Pisano

naufraganti eidem apparendo

praedixit, ut habetur in conformita-

tibus LI conformitate octa sub

littera $C$ tertia.

s. 439 W rozdziale dotyczącym gene-

ralatu Jana z Murro fragment

$+(\mathrm{k} .214 \mathrm{v})+(\mathrm{k} .117 \mathrm{v})+(\mathrm{k} .201 \mathrm{r}-$

dotyczący życia i cudów św. Lud-

203v)

wika biskupa nie zostaje prze-

dzielony żywotem Jana z Verna ${ }^{59}$.

s. 467 W rozdziale dotyczącym gene- $\quad+($ k. 224r $)+($ k. 125r)

ralatu Gondislawa drobna

lacuna: brak fragmentu dotyczą-

cego roku 1313.

s. 484 W rozdziale dotyczącym gene- $+(\mathrm{k} .228 \mathrm{v})+(\mathrm{k} .129 \mathrm{r})$

ralatu Michała z Ceseny

opuszczone jedno zdanie:

Quantum etiam rex Maior-

carum et sanctae memoriae

domina Esclarmunda, eius

consors, regina Ordinem

dilexerunt, satis ex ipsorum

primogenito domino Iacobo

Ordini oblato, qui in Ordine

finivit laudabiliter dies suos,

luculenter apparet.

s. $488 \quad$ W rozdziale dotyczącym

generalatu Michała z Ceseny

podkreślone przez M.T. Dolso

$+(\mathrm{k} .229 \mathrm{v})+(\mathrm{k} .129 \mathrm{r})+\mathrm{k} .(218 \mathrm{v})$

go złagodzenie wyrażenia noluit (?)

dotyczącego Michała z Ceseny,

który, zdaniem większości kodek-

sów officium usurpavit, tu

natomiast in officium generala-

tus voluit permanere.

s. 528 W rozdziale dotyczącym gene- $+($ k. 244v) + k. (141r)

ralatu Geralda Odonis brak

informacji dotyczącej roku 1336.

s. 530 W tym samym rozdziale nie- $\quad+(\mathrm{k} .245 \mathrm{r})+\mathrm{k} .(141 \mathrm{v})$

wielka lacuna od: nec non

frater Henricus do końca opisu

miejsc pochówków braci.

s. 543 Włączenie do głównego tekstu $+($ k. 249r $-+($ k. 144v) $+(k .241-$

${ }^{59}$ Zob. M. T. Dolso, Un nuovo manoscritto ..., s. 198. 
Kroniki (dokładnie zaś do opisu

Poza wymienionymi miejscami, które różnią zestawione powyżej kodeksy od tekstu wydania, zauważyć można istnienie wielu różnic w obrębie tytułów poszczególnych epizodów, m.in. w Vita sanctae Clarae (s. 182), gdzie wprowadzony zostaje tytuł „Incipit vita sanctae Clarae primae plantulae S. Francisci”.

Powyższe cechy rękopisów z grupy zaalpejskiej wskazywać mogą na silniejszą koncentrację kopistów na praktycznym aspekcie dzieła. Na dążenie do ułatwienia korzystania z Kroniki wskazuje sam układ tekstu podzielonego na poszczególne tytuły i rozdziały, których więcej jest tu niż w kodeksach włoskich. Szybsze odnalezienie informacji ułatwiają także noty na marginesach i osobne indeksy. Również ingerencje w tekst w pewien sposób go porządkują. Otóż mamy do czynienia z usunięciem części fragmentów, które powtarzają się w narracji Kroniki, jak na przykład w przypadku opowiadania o zniszczeniu marmurowej skarbonki Eliasza i pobłogosławieniu chleba przez św. Klarę ${ }^{62}$. Uporządkowany zostaje również żywot św. Ludwika biskupa. Ponadto w jednym z rękopisów ulega skróceniu fragment dotyczący medytacji brata Rogera, co może oznaczać, że dla kopistów tej grupy kodeksów główne znaczenie miała użyteczność Kroniki jako zbioru egzemplów, które można było wykorzystać w pracy duszpasterskiej. Takie przeznaczenie sugerują również skonwencjonalizowane zakończenia poszczególnych fragmentów (np. „qui se exaltat humiliabitur et qui se humiliat exaltabitur iuxta verbum Domini”, „et sic finem suum in bono terminavit”, „et sic in domino confortati permanserunt", itp.).

${ }^{60}$ Podobnie w kodeksie wiedeńskim i florenckim. Zob. M. T. Dolso, Un nuovo manoscritto ..., s. 198.

${ }^{61} \mathrm{~W}$ wydaniu tekst został zamieszczony w załączniku. Włączenia go do żywota Fortanerio, czyli do opowiadania o latach 1343-1347, nie da się wyjaśnić względami chronologicznymi (rzecz dzieje się bowiem w roku 1227). M. T. Dolso, Un nuovo manoscritto ..., s. 199.

62 Tamże, s. 196, 197, 204. 
O przeznaczeniu Kroniki i o stosunku skrybów do jej zawartości mogłyby coś powiedzieć wycięte miniatury kodeksu BN 8084. Wnioskowanie na podstawie tych, które pozostawiono, nie jest całkiem uprawnione, warto jednak zaznaczyć, że przedstawieni zostali na nich zwykli zakonnicy, podczas gdy np. wzmiankowany wyżej kodeks dubliński zawiera bogato zdobiony inicjał z przedstawieniem stygmatyzacji św. Franciszka, co świadczyć może o różnym rozłożeniu akcentów w poszczególnych przekazach. Dodatkowo przemawia za tym powiązanie obu kodeksów zachowanych na ziemiach polskich z zakonnikami pełniącymi posługę duszpasterską, mianowicie z Izydorem z Konina, kaznodzieją klasztoru św. Anny w Warszawie ${ }^{63}$ i Aleksym z Bobrki (czy też Bóbrki) ${ }^{64}$, pełniącym tę samą funkcję nie tylko w Warszawie, lecz także w Krakowie i Samborze, a będącym również magistrem nowicjatu w tych samych konwentach. Egzemplarz proweniencji polskiej zachowany w Strasburgu pochodzi natomiast z Krakowa, gdzie mieściło się studium generalne, przede wszystkim przygotowujące zakonników do kaznodziejstwa. Ponadto pochodzenie jednego spośród rękopisów z klasztoru w Samborze świadczy o rozpowszechnieniu tekstu niezależnie od charakteru poszczególnych placówek bernardyńskich. Sambor bowiem, w przeciwieństwie do Koła, czy Krakowa, gdzie bernardyni mieli przede wszystkim pełnić posługę duszpasterską wśród wiernych mieszczan i mieszkańców terenów podmiejskich, odgrywał rolę przyczółka zachodniego chrześcijaństwa na wschodzie ${ }^{65}$.

M. T. Dolso, powołując się na rolę kompilacji awiniońskiej i na silny związek pomiędzy Kronika a kompilacjami, sugeruje, że Kronika służyć mogła w klasztorach jako lektura w refektarzu ${ }^{66}$. Trudno jest jednak wyciągać wnioski co do roli i popularności tekstu na terenie Polski. Szczupłość źródeł i brak średniowiecznych katalogów bibliotecznych, a także nieobecność Kroniki w siedemnastowiecznych i późniejszych katalogach bernardyńskich ${ }^{67}$, nie pozwalają na stworzenie pełniejszego obrazu jej funkcjonowania.

${ }^{63}$ J. Kachel, Bernardyni 1453-2003, t. 2, s. 248.

${ }^{64}$ Tamże, t. 1 , s. 143.

${ }^{65}$ M. Maciszewska zalicza Sambor do miast należących do kategori III (Klasztor bernardyński ..., s. 87).

${ }_{66}^{6}$ M. T. Dolso, La Chronica XXIV Generalium. Il difficile percorso ..., s. 238.

${ }^{67}$ Moja kwerenda objęła następujące katalogi i inwentarze bernardyńskie, obecnie przechowywane w Archiwum Prowincji oo. Bernardynów w Krakowie: XIV-f, XIV-f-3, XXII-j-1, XXIII-5, I-h-3, I-h-1, I-h-2. Żaden nie wymienia Kroniki XXIV generatów. Trudno zatem potwierdzić słowa K. Kantaka, że Kronika „pospolicie znajdowała się po konwentach polskich”, zob. Życie wewnętrzne bernardynów $w$ dobie przedreformacyjnej, „Collectanea Theologica” 10:1929, zesz. 2, s. 338. 
Zachowane kodeksy pozwalają na powiązanie tradycji Kroniki na ziemiach polskich z drugą fazą jej popularności w ramach franciszkańskiego ruchu obserwanckiego, który narodził się w połowie XV w. Związek późnych jej przekazów ze środowiskiem obserwanckim jest zauważalny także na zachodzie. Brakuje dziś natomiast dowodu, który pozwoliłby na połączenie Kroniki ze środowiskiem polskich franciszkanów konwentualnych.

\section{Summary \\ The Manuscript Tradition of the Chronicle of the Twenty-Four Generals of the Order of Friars Minor - New Manuscript Additions}

The article presents the state of research on the Franciscan Chronicle of the Twenty-Four Generals, composed during the second half of the fourteenth century by the Minister General of Aquitaine Arnald of Sarrano. The author pays particular attention the textual tradition, supplementing the information concerning the sixteen medieval copies of the chronicle hitherto discussed in the historical literature, with the presentation of further two manuscripts, both of which are of Polish provenance. These manuscripts, preserved at the Polish National Library in Warsaw (call nos.: BOZ 1114 and BN 8084), came into being towards the end of the fifteenth century, respectively in the Observantist monasteries of Koło and Sambor. A complete codicological description is furnished with analyses of text variations, which demonstrate that both the copies in question belong to the so called „northern” group, composed chiefly of manuscripts from Halle, Lviv, Vienna, and the copy preserved in the Bibliothèque Municipale in Strasbourg, but executed in Cracow. The presented evidence also demonstrates that the chronicle was popular among the Observantists, who in Poland were known as the Bernardines. 